\title{
Epidemiology of Multiple Sclerosis in Turkey; A Ten-Year Trend in Rural Cities
}

\author{
Türkiye’de Multipl Skleroz Epidemiyolojisi; Kırsal Şehirlerdeki On Yıllık Trend
}

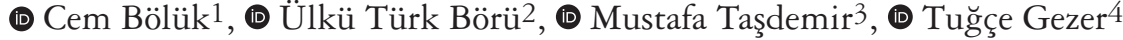 \\ ${ }^{1}$ Istanbul University-Cerrahpasa, Cerrahpasa Faculty of Medicine, Department of Neurology, Istanbul, Turkey \\ 2Afyonkarahisar University of Health Sciences, Department of Neurology, Afyon, Turkey \\ 3/stanbul Medeniyet University, Department of Public Health, Istanbul, Turkey \\ 4University of Health Sciences Turkey, Dr. Kartal Lutfi Kirdar City Hospital, Clinic of Neurology, Istanbul, Turkey
}

\begin{abstract}
Objective: Multiple sclerosis (MS) is a chronic demyelinating disease of the central nervous system that principally affects young adults. Recent studies from different parts of the world have shown that the incidence and prevalence of MS is increasing each year. No data are available on this subject for Turkey. With this study, we aimed to evaluate the 10-year trend of MS prevalence in two rural cities of Turkey for the first time.

Materials and Methods: The study was designed as a cross-sectional, community-based, descriptive epidemiologic study. Geyve and Kandıra districts were screened using a validated questionnaire between 2016-2017. During the field study, all suspected participants were invited to a public health center for reexamination along with their laboratory and imaging findings. Local state hospitals were used to complete this process if required and diagnosis was then confirmed. The revised McDonald 2010 criteria were used in diagnosing MS. Results were compared with a previous study that was conducted 10 years prior by the same team using an identical methodology.

Results: Seventeen thousand one hundred people were screened in Geyve and 12,120 people were screened in Kandıra. Ten people were diagnosed as having MS in Geyve and four were diagnosed in Kandıra. The total prevalence was found as 47.9/100,000. The female/male ratio was 2.5. Nine patients had relapsing remitting MS, four had secondary progressive MS, and one patient had primary progressive MS. When compared with the previous study, the age-standardized prevalence was not statistically different (49.6/100,000; $48.5 / 100,000 \mathrm{p}=0.955)$.
\end{abstract}

Conclusion: The results of this study indicate that the prevalence of MS is not increasing in two rural cities in Turkey.

Keywords: Population-based study, epidemiology, multiple sclerosis, prevalence, rural cities, Turkey

\section{$\ddot{O} \mathbf{z}$}

Amaç: Multipl skleroz (MS), merkezi sinir sisteminin özellikle genç erişkinleri etkileyen, kronik, demiyelinizan bir hastalığıdır. Dünyanın çeşitli bölgelerinde yapılan güncel çalışmalar, MS insidans ve prevalansının yıllar içerisinde artığını göstermektedir. Türkiye'de ise bu konuda veri bulunmamaktadır. Bu çalışma ile Türkiye'nin iki kırsal şehrinde ilk defa MS prevalansının 10 yıl içerisindeki değişimini incelemeyi amaçladık.

Gereç ve Yöntem: Bu çalışma kesitsel, toplum-bazlı, tanımlayıcı bir epidemiyolojik çalışma olarak tasarlandı. Geyve ve Kandıra ilçeleri, daha önce validasyonu yapılmış olan tarama formu kullanılarak 2016-2017 yılları arasında tarandı. Saha taraması sırasında şüphelenilen katılımcılar, laboratuvar ve görüntüleme bulgularıyla birlikte yeniden muayene edilmek üzere toplum sağlı̆̆ı merkezine davet edildi. İhtiyaç durumunda, tıbbi eksiklikleri tamamlamak için ilçe devlet hastaneleri kullanıldı ve tanı son aşamada teyit edildi. MS tanısı için revize McDonald 2010 tanı kriterleri kullanıldı. Sonuçlar 10 yıl önce aynı takım tarafından aynı metodoloji kullanılarak yapılan tarama sonuçlarıyla karşılaştırıldı.

Bulgular: Geyve'de 17.100, Kandıra 12.120 kişi tarandı. Geyve'de 10 kişiye MS tanısı konulurken Kandıra'da 4 kişiye MS tanısı konuldu. Toplam kaba prevalans 47,9/100.000 olarak bulundu. Kadın/erkek oranı 2,5 idi. Hastalardan 9'unda yineleyici ataklarla seyreden MS, 4'ünde sekonder ilerleyici MS, 1'inde primer ilerleyici MS bulunmaktaydı. Önceki çalışmayla karşılaştırıldığında, yaşa standardize prevalans değerleri istatistiksel olarak farklı değildi (49,6/100.000; 48,5/100.000 p=0,955).

Sonuç: Bu çalışmanın bulguları Türkiye’nin iki kırsal şehrinde MS prevalansında artış olmadı̆̆ını göstermektedir Anahtar Kelimeler: Toplum-temelli çalışma, epidemiyoloji, multipl skleroz, prevalans, kırsal şehirler, Türkiye

Address for Correspondence/Yazışma Adresi: Cem Bölük MD, Istanbul University-Cerrahpasa, Cerrahpasa Faculty of Medicine, Department of Neurology, Istanbul, Turkey

Phone: +90 5367172960 E-mail: cem_boluk@hotmail.com ORCID: orcid.org/0000-0003-0125-7660

Received/Geliş Tarihi: 21.03.2020 Accepted/Kabul Tarihi: 26.08.2020

${ }^{\circ}$ Copyright 2021 by Turkish Neurological Society

Turkish Journal of Neurology published by Galenos Publishing House. 


\section{Introduction}

Multiple sclerosis (MS) is a chronic demyelinating disease of the central nervous system and is the most common cause of disability in young adults, affecting over 2 million people all over the world (1). The prevalence of MS differs by genetic and geographic features and Turkey is categorized in the 20-60/100,000 group on the world MS atlas (2).

To date, two different methodologies are commonly used in epidemiologic studies of MS $(3,4,5,6)$. The first is a communitybased field study $(4,5)$. The second is a registry-based, computerized database study (6). Each approach has pros and cons but is accepted for its scientific significance. As far as is known, the first community-based epidemiologic study on MS was conducted in Galler in 1929 and it recorded a prevalence of 13/100,000 (7).

After an increasing number of studies, it was clearly understood that the prevalence and incidence of MS were increasing in many parts of the world $(8,9,10,11)$. This rise is interpreted by two different approaches. First, it might be a pseudo-increase caused by easier diagnostic methods due to magnetic resonance imaging becoming widespread and the diagnostic criteria changing frequently. The second approach is that it is in fact a genuine increase and the disease is gradually affecting more and more people. Epigenetic changes and environmental factors are held responsible through this approach $(8,9)$.

In Turkey, there are a limited number of available studies on MS epidemiology published between 2006-2020 $(12,13,14,15,16,17,18)$. However, to our knowledge, there is no study investigating the prevalence change over the years.

With this study, we aimed to investigate changes in MS prevalence by determining changes in prevalence rates in the cities of Kandira and Geyve after 10 years.

\section{Materials and Methods}

We conducted a cross-sectional, descriptive, community-based study. The STROBE guideline and checklist was followed (19). The study was conducted over 1 year between 2016 and 2017.

\section{Ethical Approval}

This study was approved by the Ethics Committee of University of Health Sciences Turkey, Kartal Dr. Lutfi Kirdar Training and Research Hospital Clinical Research (approval no: 2016/514/92/2).

\section{Characteristics of Cities}

\section{Geyve}

Geyve is the largest district of Sakarya. It is home to a homogenous Turkish population and has low immigration but a relatively high emigration rate. It has a semi-warm and wet climate mixture, which is common in the Mediterranean and Black Sea regions. The district's natural vegetation is usually forest. The economy is mainly rooted in agriculture and it has an almost nonexistent industrial establishment (20).

\section{Kandira}

Kandira is a district of Kocaeli, with a highly homogenous Turkish population and a similarly low immigration rate. It has a typical wet Black Sea region climate. The district's natural vegetation is usually oak and hornbeam forest. The economy is mainly rooted in agriculture and farming and the district has two small industrial establishments (21).

\section{Sample Size}

Based on the population of Geyve city center $(28,043)$, the sample size was calculated as 16,210 for Geyve with a confidence level of $95 \%$ and a $0.5 \%$ margin of error. To prevent a power reduction, 1000 extra participants were planned to be included in the study.

Based on the population of Kandira city center (14,291), the sample size was calculated as 10,417 with a confidence level of $95 \%$ and a $0.5 \%$ margin of error. To prevent a power reduction, 1000 extra participants were planned to be included in the study.

All neighborhoods, streets, and houses were screened door-todoor in both cities.

\section{Screening Form}

A screening form, which was prepared and validated in the Maltepe study, was used. It contained 26 questions in two parts, which first examined the symptomatology of MS before demographic features, clinical characteristics, imaging findings, lumbar punctures, and medications.

\section{Screening Team}

Before screening, four teams were put together, each had three medical students, one nurse, and one neurologist. With the permission of the local administration, medical students were chosen from faculties in each city and nurses were provided by the local public health center in each city.

Before the procedure, teams were trained at the MS center for two weeks. Previous experiences from the Geyve, Kandıra, and also İstanbul, Karabük, Akçakoca, Ordu, Gazipaşa studies, were shared.

\section{Screening Procedure}

To ensure a high participation rate, every public health center, local hospital, and city hall was equipped with information banners and announcements from city speakers, which were provided 15 days before the start of the study.

Permits and badges were provided to each member of the team, and informed consent was given by all participants.

City street maps were provided to each team for task sharing, every house was marked and screened one by one. If no one was home, the same property was revisited in the next few days until the end of the study. Screening procedures were conducted between $09.00 \mathrm{am}$ and $17.00 \mathrm{pm}$ on weekdays.

\section{Case Ascertainment}

During the screening procedure, any candidate who answered one or more questions as "yes" was re-evaluated by a neurologist on site. If the neurologist felt it necessary, participants were invited to the public health center for a clinical re-examination by a senior neurologist. Participant medical records were evaluated. Imaging studies were performed initially or repeated if needed. The diagnosis was confirmed by two neurologists, independently.

The revised McDonald 2010 criteria were used in diagnosing MS (22). Kurtzke's Expanded Disability State score (EDSS) was used to determine the disability level (23). 


\section{Statistical Analyses}

The SPSS software (version 11.5, SPSS Inc., Chicago, IL, USA) was used in calculating frequency distributions and percentages. Minitab statistical software (version 16, SPSS Inc.) was used in calculating the Poisson confidence intervals and in comparing prevalence rates.

\section{Results}

In Geyve, 17,412 persons were reached, 312 declined to participate. Seventeen thousand one hundred participants were included with a rate of $98.2 \%$. The diagnoses of 10 out of 15 invited participants who were suspected in the field study, were finally confirmed as having MS. Other participants were diagnosed as having neuromyelitis optica, lymphoma, migraine, and meningoencephalitis.

The crude prevalence of MS was found as 58.5/100,000 for Geyve.

In Kandira, 12,383 persons were reached, 263 declined to participate in the study. Twelve thousand one hundred twenty participants were included with a participation rate of $97.9 \%$. The diagnoses of four out of seven suspected participants were finally confirmed as MS. Others were diagnosed as having polyneuropathy, lupus, and migraine.

The crude prevalence of MS was found as 33.1/100,000 for Kandira.

In total, 29,220 participants were reached, 14 were diagnosed as having MS and the prevalence was found as 47.9/100,000. When compared with a study from 10 years previously, the result was almost the same, no statistical increase was shown (47.6/100,000, $\mathrm{p}=0.988)$. After age standardization, the prevalence was found as 49.6/100,000 and 48.5/100,000, respectively ( $\mathrm{p}=0.955)$.

We found 10 new patients in this study and 8 previous patients were not present due to exitus or migration. The diagnosis year of participants is shown in Table 1.

Nine patients were classified as having relapsing-remitting MS, four had secondary progressive MS, and one had primary progressive MS. The diagnosis age range varied between 15 and 42 years. The EDSS range was found to be between 1.0 and 8.0. The most common initial symptom was optic neuritis and hemiparesis.

The demographic and clinical characteristics of the patients are summarized in Table 2. The initial symptom distribution is

\begin{tabular}{|lll|}
\hline Table 1. Diagnosis years of 10 new patients \\
\hline Patient number & Sex & Year of diagnosis \\
1 & M & 2007 \\
2 & F & 2007 \\
3 & F & 2009 \\
4 & M & 2010 \\
5 & M & 2010 \\
6 & F & 2012 \\
7 & M & 2014 \\
8 & F & 2016 \\
9 & F & 2016 \\
10 & F & 2017 \\
M: Male, F: Female & & \\
\hline
\end{tabular}

shown in Table 3. The classification of patients is shown in Figure 1. The distribution of age at MS diagnosis is shown in Figure 2.

\section{Discussion}

This study showed the prevalence of MS once again in two important rural cities in Turkey after 10 years. The total prevalence of 47.9/100,000 is accordant with Turkey's average (2). No significant increase was recorded in 10 years when compared with previous study results (13).

In 2007,12 patients out of 25,187 participants who were screened using exactly the same methodology with the same team

\begin{tabular}{|ll|}
\hline $\begin{array}{l}\text { Table 2. Demographic and clinical characteristics of the } \\
\text { patients }\end{array}$ & 14 \\
Patient number & $47.9 / 100,000$ \\
Prevalence of MS & $39.8 \pm 9.8$ \\
Mean age, year & $26.7 \pm 8.4$ \\
Mean age at diagnosis & 2.5 \\
Female/male ratio & $14.5 \pm 8.4$ \\
Duration of disease, year $( \pm$ SD) & 3.0 \\
Median EDSS & $70 \%$ \\
$\begin{array}{l}\text { Oligoclonal bands positivity } \\
\text { MS: Multiple sclerosis, EDSS: Expanded Disability State score, SD: Standard } \\
\text { deviation }\end{array}$ \\
\hline
\end{tabular}

\section{Table 3. Distribution of initial symptoms}

\begin{tabular}{ll|} 
Symptoms & $\mathbf{n},(\%)$ \\
Pyramidal & $5,(35.7 \%)$ \\
Cerebellar & $2,(14.2 \%)$ \\
Brainstem & $3,(21.4 \%)$ \\
Sensory & $3,(21.4 \%)$ \\
Autonomic & $1,(7.1 \%)$ \\
Visual & $4,(28.6 \%)$ \\
\hline
\end{tabular}

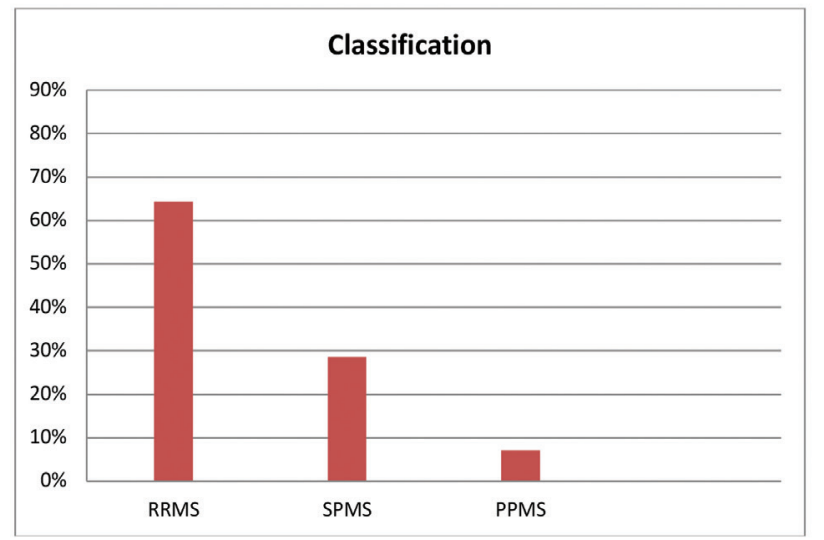

Figure 1. Classification of patients with MS

RRMS: Relapsing remitting multiple sclerosis, SPMS: Secondary progressive multiple sclerosis, PPMS: Primary progressive multiple sclerosis, MS: Multiple sclerosis 


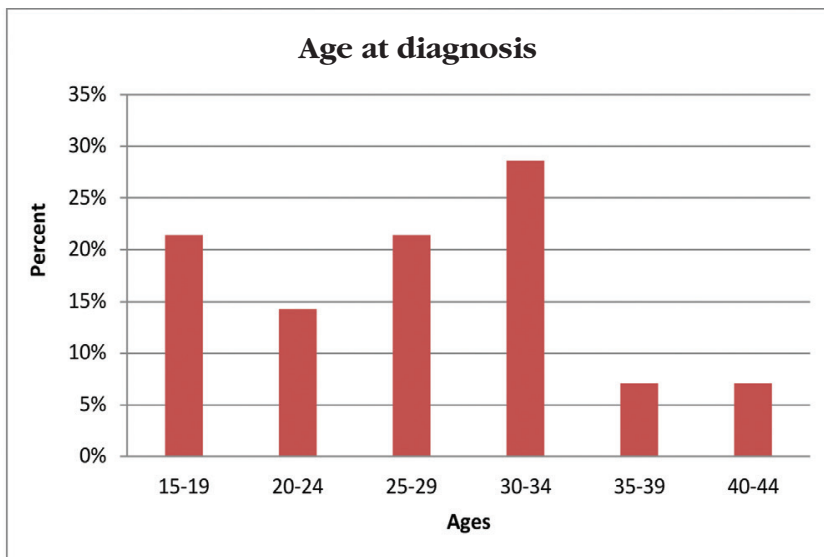

Figure 2. The distribution of age at diagnosis

supervisor, were diagnosed as having MS. Ten patients were newly added and eight patients were not present in this study ( 5 exitus, 3 migrated).

Despite not being a prospective cohort study, with these findings, we were allowed to gain insight into the incidence of MS for the first time in Turkey. The distribution of the diagnosis years of patients showed us that every two years, two new patients developed MS. All new patients were known to be domestic people and not immigrants and they had no symptoms prior to their diagnosis year. Therefore, the annual incidence rate can be interpreted as 3.4/100,000.

The factors contributing to this stable prevalence may be the low immigration rate, the low urbanization rate, and low levels of air pollution along with stable socioeconomic levels and dietary habits. This is because when the epidemiologic studies that reported an increase in MS prevalence were analyzed, it was understood that this was due to changing environmental factors, dietary habits, immigration, and toxin exposure $(24,25,26,27,28,29)$. Both Geyve and Kandira are rural cities that have no serious industrialization and air pollution (30).

Turkey has other cities such as İstanbul, Karabük, and Ereğli, which have much higher MS prevalences 101.4/100,000; $95.9 / 100,000$ and $96.1 / 100,000$, respectively $(12,16,18)$ with their high urbanization index and high air pollution levels (30). In addition, the lowest MS prevalence (18.6/100,000) was found in Artvin, which is the titleholder of the nation's cleanest city (17). These cities, which are located on the same latitude, are important examples in showing the effects of air pollution and urbanization. Many studies from different countries have also shown the effects of air pollution on MS epidemiology (31,32,33,34,35). These Italian, French, Iranian, and Finnish studies showed that increased $\mathrm{PM}_{2.5}, \mathrm{PM}_{10}, \mathrm{CO}_{2}$ and $\mathrm{NO}_{2}$ levels were risk factors for MS.

Similar to our findings, various studies also showed no increase and even a decrease in the incidence of MS $(36,37,38,39,40)$. They reported that the incidence of MS was stable or had decreased, but the prevalence had increased slightly with the increase in life expectancy. A Canadian study stated that in some studies that showed an increase in MS incidence and prevalence after the second screening, cases were overlooked in the previous one and resulted in a pseudo-increase. Also, methodologic differences were stated as the other main cause of this rise (41). With all this taken into consideration, in our study, the methodology was identical to the previous study and it was understood from the diagnosis years that no cases were overlooked.

The female/male ratio is again similar to the previous study and other national studies $(12,13,14,15,16,17,18)$. A large metaanalysis showed that the ratio increased from 1.4 to 2.3 between 1950 and 2000, but showed no change in the last 10 years (42). Again, a very recent study that was published in 2018 recorded that the female/male ratio was stable in 2.4 in the last 15 years (36).

The mean and median EDSS of the patients were a little high in this study when compared with other studies $(12,13,14,18)$. The reason may be due to the relatively high disease duration and low patient number. On the other hand, we detected no patients with late-onset MS in these cities. In general, 5-10\% of all patients with MS are expected to have disease onset later than age 45 years (43). The low number of cases could again be responsible for this situation.

\section{Study Limitations}

The main limitation of this study is that it is a cross-sectional self-declaration-based study. Recall bias may be one of the main problems in patients with MS. Another limitation may be that fulfilling the McDonald criteria may not be enough in distinguishing MS mimickers. Finally, important environmental factors such as vitamin D, cigarette smoking or Epstein-Barr virus infection rates were not investigated.

\section{Conclusion}

With this first study, which investigated the changes in MS epidemiology in Turkey in nearly 30,000 participants and had high participation rates, we conclude that the prevalence of MS is not increasing, at least in these two rural cities. More studies are needed, particularly in urban cities to shed light on changes in MS epidemiology in Turkey.

\section{Ethics}

Ethics Committee Approval: This study was approved by the Ethics Committee of University of Health Sciences Turkey, Kartal Dr. Lutfi Kirdar Training and Research Hospital Clinical Research (approval no: 2016/514/92/2).

Informed Consent: Informed consent was given by all participants.

Peer-review: Externally peer-reviewed.

\section{Authorship Contributions}

Concept: C.B., Ü.T.B., M.T., Design: C.B., Ü.T.B., T.G., Data Collection or Processing: C.B., Ü.T.B., M.T., T.G., Analysis or Interpretation: C.B., Ü.T.B., M.T., Literature Search: C.B., Ü.T.B., T.G., Writing: C.B., Ü.T.B., M.T., T.G.

Conflict of Interest: No conflict of interest was declared by the authors.

Financial Disclosure: The authors declared that this study received no financial support.

\section{References}

1. Zwibel HL, Smrtka J. Improving quality of life in multiple sclerosis: an unmet need. Am J Manag Care 2011;17(Suppl 5):139-145. 
2. Browne P, Chandraratna D, Angood C, et al. Atlas of multiple sclerosis 2013: A growing global problem with widespread inequity. Neurology 2014;83:1022-1024

3. Anderson DW, Ellenberg JH, Leventhal CM, et al. Revised estimate of the prevalence of multiple sclerosis in the United States. Ann Neurol 1992;31:333-336.

4. Baum HM, Rothschild BB. The incidence and prevalence of reported multiple sclerosis. Ann Neurol 1981;10:420-428.

5. Campbell JD, Ghushchyan V, Brett McQueen R, et al. Burden of multiple sclerosis on direct, indirect costs and quality of life: national US estimates. Mult Scler Relat Disord 2014;3:227-236.

6. Noonan CW, Kathman SJ, White MC. Prevalence estimates for MS in the United States and evidence of an increasing trend for women. Neurology 2002; $58: 136-138$.

7. Allison RS. Disseminated sclerosis in North Wales: an inquiry into its incidence, frequency, distribution and other etiological factors. Brain 1931;53:391-430.

8. Sellner J, Kraus J, Awad A, et al. The increasing incidence and prevalence of female multiple sclerosis-a critical analysis of potential environmental factors. Autoimmun Rev 2011;10:495-502.

9. Nicoletti A, Patti F, Lo Fermo S, et al. Possible increasing risk of multiple sclerosis in Catania, Sicily. Neurology 2005;65:1259-1263

10. Grytten N, Glad SB, Aarseth JH, et al. A 50-year follow-up of the incidence of multiple sclerosis in Hordaland County, Norway. Neurology 2006;66:182-186.

11. Granieri E, Casetta I, Govoni V, et al. The increasing incidence and prevalence of MS in a Sardinian province. Neurology 2000;55:842-848.

12. Türk Börü U, Alp R, Sur H, Gül L. Prevalence of multiple sclerosis door-todoor survey in Maltepe, Istanbul, Turkey. Neuroepidemiology 2006;27:1721.

13. Börü UT, Taşdemir M, Güler N, et al. Prevalence of multiple sclerosis: doorto-door survey in three rural areas of coastal Black Sea regions of Turkey. Neuroepidemiology 2011;37:231-235.

14. Çelik Y, Birgili Ö, Kiyat A, et al. Prevalence of multiple sclerosis in the metropolitan area of Edirne City, Turkey. Balkan Med J 2011;28:193-196.

15. Akdemir N, Terzi M, Arslan N, Onar M. Prevalence of multiple sclerosis in the Middle Black Sea region of Turkey and demographic characteristics of patients. Noro Psikiyatr Ars 2017;54:11-14.

16. Türk Börü Ü, Bilgiç AB, Köseoğlu Toksoy C, et al. Prevalence of multiple sclerosis in a Turkish city bordering an iron and steel factory. J Clin Neurol 2018;14:234-241.

17. Türk Börü Ü, Duman A, Kulualp AŞ, et al. Multiple sclerosis prevalence study: The comparison of 3 coastal cities, located in the black sea and mediterranean regions of Turkey. Medicine (Baltimore) 2018;97:e12856

18. Türk Börü Ü, Bölük C, Taşdemir M, Gezer T, Serim VA. Air pollution, a possible risk factor for multiple sclerosis. Acta Neurol Scand 2020;141:431437.

19. Von Elm E, Altman DG, Egger M, et al. The Strengthening the Reporting of Observational Studies in Epidemiology (STROBE) statement: guidelines for reporting observational studies. PLoS Med 2007;4:e296.

20. Geyve Belediyesi (TR). Online city information [Internet]. Sakarya: Geyve Municipality; 2016. Last Accessed Date: 01.12.2016. Available from: www. geyve.bel.tr

21. Kandıra Belediyesi (TR). Online city information [Internet]. Kocaeli: Kandıra Municipality; 2016. Last Accessed Date: 01.12.2016. Available from: www.kandira.bel.tr

22. Polman $\mathrm{CH}$, Reingold SC, Banwell B, et al. Diagnostic criteria for multiple sclerosis: 2010 revisions to the McDonald criteria. Ann Neurol 2011;69:292-302.
23. Kurtzke JF. Rating neurologic impairment in multiple sclerosis: an expanded disability status scale (EDSS). Neurology 1983;33:1444-1452.

24. Pugliatti M, Sotgiu S, Solinas G, et al. Multiple sclerosis epidemiology in Sardinia: evidence for a true increasing risk. Acta Neurol Scand 2001;103:20-26.

25. Midgard R, Riise T, Svanes C, Kvåle G, Nyland H. Incidence of multiple sclerosis in Møre and Romsdal, Norway from 1950 to 1991. An age-periodcohort analysis. Brain 1996;119:203-211.

26. Houzen $H$, Niino $M$, Hata $D$, et al. Increasing prevalence and incidence of multiple sclerosis in northern Japan. Mult Scler 2008;14:887-892.

27. Etemadifar M, Maghzi AH. Sharp increase in the incidence and prevalence of multiple sclerosis in Isfahan, Iran. Mult Scler 2011;17:1022-1027.

28. Hirst C, Ingram G, Pickersgill T, et al. Increasing prevalence and incidence of multiple sclerosis in South East Wales. J Neurol Neurosurg Psychiatry 2009;80:386-391.

29. Sumelahti ML, Tienari PJ, Wikström J, Palo J, Hakama M. Increasing prevalence of multiple sclerosis in Finland. Acta Neurol Scand 2001;103:153-158.

30. T.C. Cevre ve Sehircilik Bakanligi. Ulusal Hava Kalitesi İzleme İstasyonlar official wesite [Internet]. Ankara: National Air Pollution Monitoring Network System; 2018. Last Accessed Date: 01.02.2018. Available from www.havaizleme.gov.tr

31. Angelici L, Piola M, Cavalleri T, et al. Effects of particulate matter exposure on multiple sclerosis hospital admission in Lombardy region, Italy. Environ Res 2016;145:68-73.

32. Tateo F, Grassivaro F, Ermani M, Puthenparampil M, Gallo P. PM2.5 levels strongly associate with multiple sclerosis prevalence in the Province of Padua, Veneto Region, North-East Italy. Mult Scler 2019;25:1719-1727.

33. Oikonen M, Laaksonen M, Laippala P, et al. Ambient air quality and occurrence of multiple sclerosis relapse. Neuroepidemiology 2003;22:9599.

34. Heydarpour P, Amini H, Khoshkish S, et al. Potential impact of air pollution on multiple sclerosis in Tehran, Iran. Neuroepidemiology 2014;43:233238.

35. Roux J, Bard D, Le Pabic E, et al. Air pollution by particulate matter PM10 may trigger multiple sclerosis relapses. Environ Res 2017;156:404-410.

36. Rotstein DL, Chen H, Wilton AS, et al. Temporal trends in multiple sclerosis prevalence and incidence in a large population. Neurology 2018;90:e1435-e1441.

37. Eliasdottir OJ, Olafsson E, Kjartansson O. Incidence of multiple sclerosis in Iceland, 2002-2007: A population-based study. Mult Scler 2011;17:909913.

38. Celius EG, Vandvik B. Multiple sclerosis in Oslo, Norway: prevalence on 1 January 1995 and incidence over a 25-year period. Eur J Neurol 2001;8:463469.

39. Hader WJ, Yee IML. Incidence and prevalence of multiple sclerosis in Saskatoon, Saskatchewan. Neurology 2007;69:1224-1229.

40. Svenningsson A, Runmarker B, Lycke J, Andersen O. Incidence of MS during two fifteen-year periods in the Gothenburg region of Sweden. Acta Neurol Scand 1990;82:161-168.

41. Orton SM, Herrera BM, Yee IM, et al. Sex ratio of multiple sclerosis in Canada: A longitudinal study. Lancet Neurol 2006;5:932-936.

42. Alonso A, Hernán MA. Temporal trends in the incidence of multiple sclerosis: a systematic review. Neurology 2008;71:129-135.

43. Paty D, Boiko A, Vorobeichik G. Multiple sclerosis with early and late disease onset. In: McDonald WI, Noseworthy J, (eds). Multiple Sclerosis 2. Boston: Butterworth Heinemann; 2003:285-302. 